
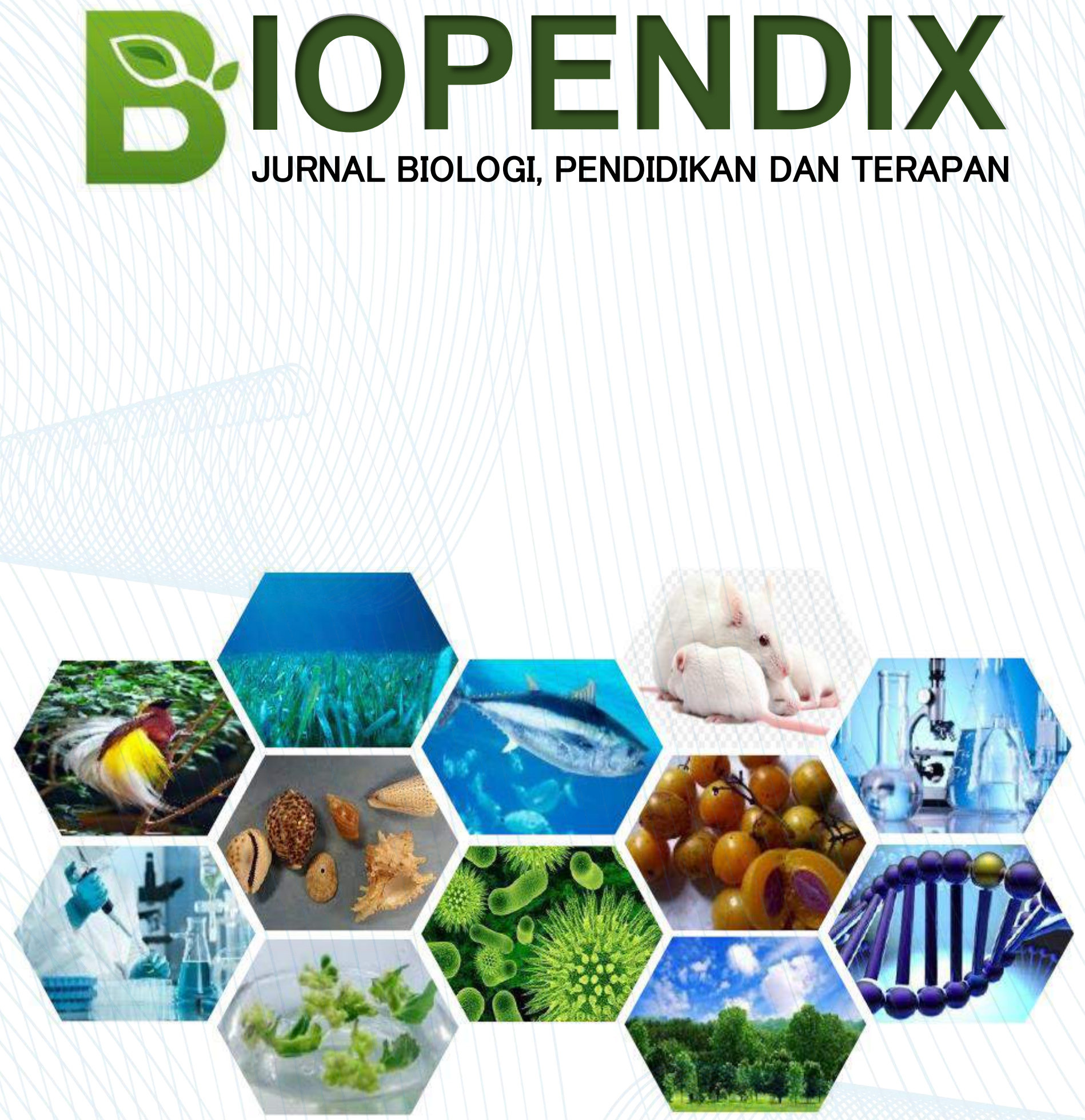

PUBLISHER BY:

BIOLOGY EDUCATION, UNPATTI AMBON - MALUKU 


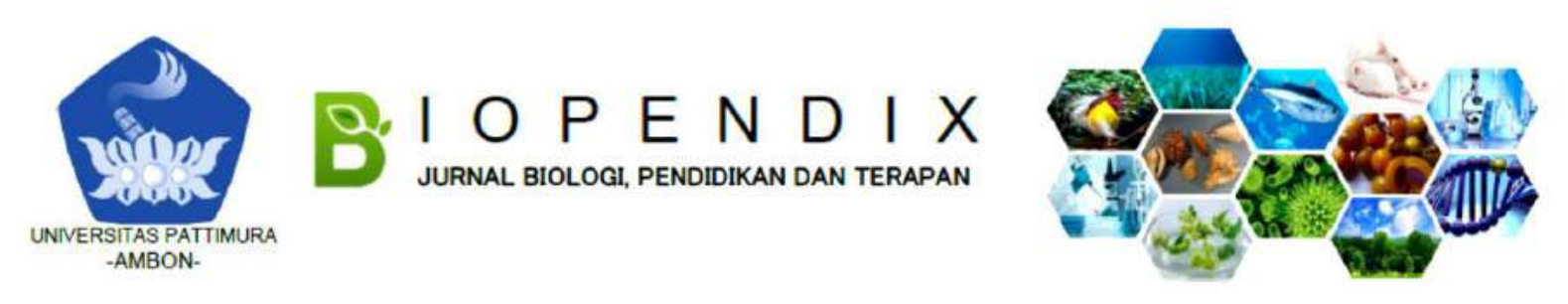

\title{
ANALISIS KADAR KARBOHIDRAT DAN LEMAK PADA TEMPE BERBAHAN DASAR BIJI LAMUN (Enhalus acoroides)
}

\author{
Haslina Kole ${ }^{1}$, Prelly Tuapattinaya ${ }^{2}$, Theopilus Watuguly ${ }^{\star 2}$ \\ ${ }^{1}$ Mahasiswa Program Studi Pendidikan Biologi; \\ ${ }^{2}$ Dosen Program Studi Pendidikan Biologi
}

*Corresponding author: Theopilus Watuguly; e-mail: twwatuguly.unpatti@gmail.com

\begin{abstract}
Background: Seagrass (Enhalus Acoroides) is one of the most widely spread seagrass species in Indonesia and the seeds can be used by the community to be semi-processed product like Tempe (Fermented soyben). Another advantage possessed by Seagrass (Enhalus Acoroides) is that it has quite high nutrition. This research aimed to find out the carbohydrate and fat level on Tempe made from the fermentation of the seagrass seeds (Enhalus acoroides).

Method: The analysis of the level of carbohydrate used by different method while the fat used Soxhlet method.

Result: Based on the result of the research if the seagrass seeds been processed to be tempe, thus the carbohydrate and fat level was increased with the comparison of appropriate yeast.

Conclusion: raw seagrass seeds if being processed to be tempe can increase the level of nutrition with the ppropriate amount of the yeast compared to consuming directly.
\end{abstract}

Keywords: Seagrass Seeds (Enhalus acoroides) Carbohydrate, Fat

\section{Abstrak}

Latar Belakang: Lamun Enhalus acoroides merupakan salah satu jenis lamun yang paling banyak tersebar di Indonesia dan dapat di manfaatkan bijinya oleh masyarakat menjadi produk olahan makanan setengah jadi seperti tempe. Kelebihan lain yang dimiliki Enhalus acoroides yaitu memiliki nilai gizi yang cukup tinggi. Penelitian ini bertujuan untuk mengetahui kadar karbohidrat dan lemak pada tempe berbahan dasar biji lamun.

Metode: Analisis kadar karbohidrat menggunakan metode by different sedangkan pada lemak menggunakan metode soxhlet.

Hasil: Berdasarkan hasil penelitian biji lamun jika diolah menjadi tempe maka kadar karbohidrat dan lemaknya meningkat dengan perbandingan ragi yang sesuai. Kesimpulan: biji lamun mentah jika diolah menjadi tempe mampu meningkatkan kadar gizinya dengan jumlah takaran ragi yang sesuai dibandingkan memakannya secara langsung.

Kata kunci : Biji lamun, Karbohidrat, Lemak 


\section{PENDAHULUAN}

Lamun (seagrass) merupakan tumbuhan berbunga (angiospermae) yang sudah sepenuhnya menyesuaikan diri hidup terbenam di dalam laut. Lamun memiliki fungsi yang sangat penting yaitu sebagai produsen primer, sebagai habitat biota, sebagai penangkap sedimen serta penahan arus dan gelombang, dan sebagai pendaur zat hara. Di perairan Indonesia terdapat 15 jenis, yang terdiri atas 2 suku dan 7 marga. Jenis lamun yang dapat dijumpai adalah 12 jenis, Dari 15 jenis lamun yang tersebar di perairan Indonesia, ada salah satu yang dapat dimanfaatkan oleh masyarakat yaitu jenis Enhalus acoroides. Jenis lamun ini paling banyak hidup tersebar di perairan dan mampu hidup di berbagai substrat. Kelebihan lain yang dimiliki Enhalus acroides yaitu memiliki nilai gizi yang cukup tinggi. Hasil analisis menunjukkan bahwa di samping itu keistimewaan secara ekonomis biji Enhalus acoroides dapat dimanfaatkan sebagai bahan makanan karena memiliki kandungan nutrisi karbohidrat yang relatif tinggi yaitu $72,4 \%$, kandungan protein sebesar $8,1 \%$, lemak sebesar $0,2 \%$, kandungan air sebesar $9,8 \%$, serat sebesar 2,4\%, abu sebesar 6,4\% (Muskita, 2016).

Karbohidrat merupakan salah satu zat gizi yang diperlukan oleh manusia yang befungsi untuk menghasilkan energi bagi tubuh manusia. Karbohidrat sebagai zat gizi merupakan nama kelompok zat-zat organik yang mempunyai struktur molekul yang berbeda-beda, meski terdapat persamaanpersamaan dari sudut kimia dan fungsinya. Semua karbohidrat terdiri atas unsur Carbon $(\mathrm{C})$, hidrogen $(\mathrm{H})$, dan oksigen $(\mathrm{O})$ dengan rumus kimia $\mathrm{Cn}\left(\mathrm{H}_{2} \mathrm{O}\right) n$, (Siregar N S. 2014).

Karbohidrat selain berfungsi untuk menghasilkan energi, juga mempunyai fungsi yang lain bagi tubuh. Fungsi lain karbohidrat yaitu pemberi rasa manis pada makanan, penghemat protein, pengatur metabolisme lemak, membantu pengeluaran feses, (Siregar N S. 2014)

Lemak merupakan zat makanan yang penting untuk menjaga kesehatan tubuh manusia. Lemak memiliki beberapa fungsi dalam tubuh, yaitu sebagai sumber energi dan pembentukan jaringan adipose. Lemak merupakan sumber energi paling tinggi yang menghasilkan 9 kkal untuk tiap gramnya, yaitu 2,5 kali energi yang dihasilkan oleh karbohidrat dan protein dalam jumlah yang sama (Gifari, 2011). Menurut Koswara (2006), lemak akan menghasilkan asamasam lemak dan kolestrol yang dibutuhkan untuk membentuk membrane sel pada semua organ. Akan tetapi, konsumsi lemak yang berlebihan akan menimbulkan kegemukan, meningkatkan resiko terkena penyakit jantung koroner dan penyakit degeneratif lainnya.

Lemak mempunyai peran penting dalam tubuh manusia, sebab lemak adalah sumber energi yang tinggi. Satu gram lemak sesuai dengan rekomendasi dari Food and Nutrition Board of the Natioanal Research Council pada tahun 1948 , bahwa antara $20 \%$ sampai $25 \%$ kalori hendaknya datang dari lemak. Bila 408 kalori, haruslah berasal dari lemak. Hal ini berarti kita memerlukan sedikitnya 46 gram lemak per hari (Kuantaf dan Kuantaraf, 1999).

Produktivitas lamun di laut dapat melebihi produktivitas dari beberapa tanaman darat misalnya gandum, jagung, beras dan tebu. Produktivitas yang tinggi dari lamun ini, belum diimbangi dengan pemanfaatannya secara optimal (Rumiantin 2011). Perlu ada cara agar masyarakat dapat mengolah biji lamun menjadi sesuatu bahan jadi yang dapat bertahan lama dan memiliki nilai jual serta kandungan gizi (Tuapattinaya 2016). Salah satu caranya yaitu dengan mengubah biji lamun menjadi produk setengah jadi seperti tempe.

Tempe adalah sumber protein yang penting dalam menu makanan Indonesia yang merupakan bahan makanan lauk pauk nabati atau sebagai sumber protein nabati. Tempe sangat mudah dicerna, sehingga baik untuk orang yang terkena gangguan pencernaan. Kapang Rhyzopus yang dipakai pada pembuatan tempe, mampu memproduksi enzim yang memecah senyawa organik kompleks menjadi lebih sederhana, sehingga mudah diserap tubuh. Proses pembuatan tempe juga akan menghambat bahkan menghentikan aktivitas zat antigizi. Hal ini membuktikan bahwa tempe aman dan menyehatkan untuk dimakan (Koswara, 1995). Menurut Kasdmidjo (1990), beberapa penelitian menunjukkan bahwa zat gizi tempe lebih mudah dicerna, diserap, dan dimanfaatkan tubuh. Hal ini dikarenakan kapang yang tumbuh pada kedelai menghidrolisis 
senyawa-senyawa kompleks menjadi senyawa sederhana yang mudah dicerna oleh manusia.

\section{METODE}

Penelitian ini menggunakan tipe penelitian eksperimental yaitu untuk melihat kadar lemak dan karbohidrat pada tempe berbahan dasar Biji lamun (Enhalus acoroides), yang dilaksanakan di laboratorium. Tempat pengambilan sampel biji lamun Enhalus acroides di Desa Suli Kecamatan Salahutu Kabupaten Maluku Tengah. Penelitian ini berlangsung selama 1 bulan yaitu 28 Agustus-28 September 2018.

\section{Tahap Persiapan Sampel}

a. Sampel diambil diperairan Pantai Desa Suli

b. Buah lamun dicuci dan dilepaskan biji dari daging buahnya

c. Biji lamun dipotong-potong menjadi kecil-kecil.

d. Selanjutnya di timbang $200 \mathrm{~g}$ untuk proses pembuatan tempe.

\section{Proses Pembuatan Tempe}

a. Biji lamun yang sudah dipotong disiapkan dan diletakkan pada panci kemudian direndam selama 1 malam kurang lebih 12 jam

b. Selanjutnya, biji lamun dicuci pada air mengalir

c. Rebus biji lamun sampai air mendidih sekitar 30 menit

d. Angkat biji lamun dan didinginkan pada nampan

e. Setelah dingin, diangin-anginkan biji lamun sampai terlihat kering.

f. Selanjutnya, campurkan biji lamun dengan ragi sesuai takaran 5gram, 10 gram dan $15 \mathrm{gram}$.

g. Kemudian, masukkan biji lamun tersebut ke dalam plastik yang telah disediakan dan ditusuk bagianbagiannya dengan menggunakan tususk gigi

h. Fermentasikan bakal tempe tersebut ke tempat yang kering selama 48 jam

i. Setelah tempe siap, maka dilakukan proses uji kadar karbohidrat dan uji kadar lemak

\section{Tahap Uji Kadar Lemak}

Analisis kadar lemak dilakukan dengan metode soxhlet (AOAC, 2005). Prinsipnya adalah lemak yang terdapat dalam sampel diekstrak dengan menggunakan pelarut non polar.

a. Labu lemak yang akan digunakan dioven selama 30 menit pada suhu $100-105^{\circ} \mathrm{C}$.

b. Selanjutnya labu lemak didinginkan dalam desikator untuk menghilangkan uap air dan ditimbang.

c. Sampel ditimbang sebanyak $2 \mathrm{~g}$.

d. kemudian dibungkus dengan kertas saring, ditutup dengan kapas bebas lemak dan dimasukkan ke dalam soxhlet yang telah dihubungkan dengan labu lemak.

e. Sampel sebelumnya telah dioven dan diketahui bobotnya.

f. Pelarut heksan dituangkan sampai sampel terendam dan dilakukan refluks atau ektraksi selama 5-6 jam atau sampai palarut lemak yang turun ke tempe berwarna jernih.

g. Pelarut lemak yang telah digunakan, disuling, dan ditampung.

h. Ekstrak lemak yang ada dalam labu lemak dikeringkan dalam oven bersuhu 100-105ㄷ Celama 1 jam.

i. Labu lemak didinginkan dalam desikator dan ditimbang.

j. Tahap pengeringan labu lemak diulangi sampai diperoleh bobot yang konstan.

k. Tahap analisis kadar lemak ini dilakukan sebanyak 3 kali sesuai dengan perlakuan pada tempe yang diberi ragi sesuai takaran $5 \mathrm{~g}, 10 \mathrm{~g}$ dan $15 \mathrm{~g}$.

\section{Uji Kadar Karbohidrat}

Penentuan kadar karbohidrat dihitung menggunakan metode by difference Analisis kadar karbohidrat dihitung dengan cara perhitungan kasar (analisis proksimat) atau yang disebut Carbohydrate by difference. Jumlah w1 - w2 w2 X 100\% X $100 \%(b-a) \times \times 100 \%$ persentase kadar protein, air, abu dan lemak dihitung. Karbohidrat dapat diketahui melalui formulasi sebagai berikut: Kadar karbohidrat : $100 \%$ - \% (protein + lemak + air + abu) (Ristia, 2014).

\section{Teknik Analisis Data}

Berdasarkan hasil penelitian yang diperoleh maka analisis data karbohidrat dan 
lemak dapat menggunakan rumus sebagai berikut:

Penentuan uji kadar lemak dihitung dengan menggunakan rumus sebagai berikut:

Lemak total $(\%)=\frac{(C-A) \times 100 \%}{B}$

Keterangan :

a: berat labu alas bulat kosong $(\mathrm{g})$

$\mathrm{b}$ : berat sampel $(\mathrm{g})$

c: berat labu alas bulat dan lemak hasil ekstraksi (g)

Penentuan uji kadar karbohidrat dihitung dengan menggunakan rumus sebagai berikut: Karbohidrat $(\%)=100 \%$ (kadar air + kadar protein + kadar abu + kadar lemak).

\section{HASIL DAN PEMBAHASAN}

\section{Uji Kadar Karbohidrat}

Berdasarkan hasil analisis, diketahui banyaknya kandungan karbohidrat yang terdapat pada biji lamun, seperti pada hasil berikut.

\section{Tabel 3. Hasil Penelitian Uji Kandungan} Karbohidrat.

\begin{tabular}{ccc}
\hline No & Sampel & Karbohidrat (\%) \\
\hline 1 & R0 & 9.48 \\
2 & R1 & 16.24 \\
3 & R2 & 13.90 \\
4 & R3 & 5.49 \\
\hline Ket: & R0(Biji Lamun Mentah) \\
& R1(tempe dengan ragi 05 gram) \\
& R2(tempe dengan ragi 10 gram) \\
& R3(tempe dengan ragi 15 gram)
\end{tabular}

Berdasarkan tabel 3 dapat dilihat bahwa kadar karbohidrat per sampel menunjukan hasil yang berbeda, dimana $\mathrm{R} 1=16.24 \%, \mathrm{R} 2=13.90 \%$, dan $\mathrm{R} 3=5.49 \%$. Sedangkan pada R0 (kontrol) $=9.48 \%$.

\section{Uji Kadar Lemak}

Berdasarkan hasil analisis, diketahui banyaknya kandungan lemak yang terdapat pada biji lamun, seperti pada hasil berikut.
Tabel 2. Hasil Penelitian Uji Kandungan Lemak.

\begin{tabular}{ccc}
\hline No & Sampel & Lemak (\%) \\
\hline 1 & R0 & 1.83 \\
2 & R1 & 2.37 \\
3 & R2 & 2.74 \\
4 & R3 & 2.13 \\
\hline Ket: & R0(Biji Lamun Mentah) \\
\multicolumn{3}{c}{ R1(tempe dengan ragi 5gram) } \\
\multicolumn{2}{c}{ R2(tempe dengan ragi 10gram) } \\
\multicolumn{2}{l}{ R3(tempe dengan ragi 15gram) }
\end{tabular}

Berdasarkan hasil penelitian tergambar bahwa kadar lemak pada setiap perlakuan berbeda-beda dapat dilihat penambahan konsentrasi ragi mempengaruhi kadar lemak yang dihasilkan pada tempe biji lamun. Biji lamun tanpa perlakuan (R0) jumlah total kadar lemaknya $1.83 \%$, dan mengalami peningkatan pada perlakuan R1 dan R2 dengan pemberian ragi 5 dan 10 gram kadar lemak yang dihasilkan yaitu $2.37 \%$ dan $2.74 \%$, tetapi mengalami penurunan yang tidak signifikan pada pemberian ragi 15 gram total kadar lemaknya adalah $2.13 \%$.

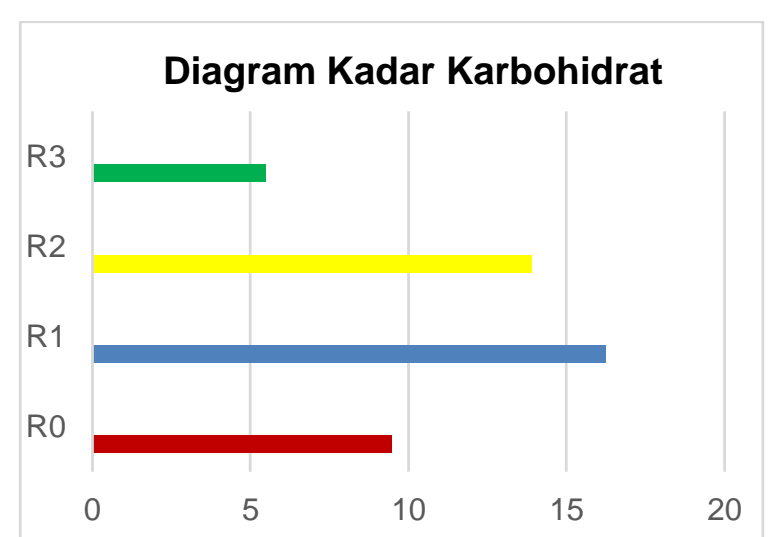

(Data primer, 2018)

Ket: R0 (Biji Lamun Mentah)

$\mathrm{R} 1$ (tempe dengan ragi 05gram)

$\mathrm{R} 2$ (tempe dengan ragi 10gram)

R3 (tempe dengan ragi 15gram)

Kadar Karbohidrat pada tempe berbahan dasar biji lamun dianalisis menggunakan metode by different dengan pemberian konsentrasi ragi yang berbeda. gambar 3. menunjukkan grafik perbedaan kadar karbohidrat pada setiap perlakuan. Biji lamun mentah (R0) memiliki kadar karbohidrat sebesar $9.48 \%$, sedangkan pada perlakuan pertama (R1) yaitu dengan pemberian ragi sebanyak 05 gram 
menghasilkan kadar karbohidrat sebesar $16.24 \%$, perlakuan kedua (R2) dengan pemberian ragi $10 \mathrm{gram}$ kadar karbohidrat yang dihasilkan $13.90 \%$ dan perlakuan ketiga (R3) dengan ragi sebanyak $15 \mathrm{gram}$ menghasilkan karbohidrat dengan kadar $5.49 \%$.

Pada biji lamun mentah mengalami peningkatan jika diolah menjadi tempe biji lamun, dapat dilihat dari gambar 3. bahwa pada perlakuan $\mathrm{R} 1$ dengan pemberian ragi 5gram mengalami peningkatan kadar karbohidrat dengan selisih $6.76 \%$, tetapi mengalami penurunan pada R3 dengan pemberian ragi $15 \mathrm{gram}$. Hal tersebut disebabkan oleh adanya kerja enzim yang dihasilkan oleh mikroba itu sendiri dan enzim tersebut bersifat katabolik atau memecah senyawa-senyawa yang kompleks menjadi sederhana sehingga mudah dicerna (Pawiroharsono, 2007). Mikroba menggunakan komponen kimia didalam substrat sebagai sumber energi untuk berkembang biak dan menghasilkan sel baru (Subagio, 2002). Hal ini serupa dengan penelitian Nuriana (2009) yang mengatakan bahwa karbohidrat yang terkandung dalam biji nangka dan kedelai digunakan oleh kapang sebagai bahan makanannya.

Berdasarkan analisis kadar karbohidrat di atas, menunjukkan bahwa pada setiap perlakuan menghasilkan kadar yang berbeda-beda. Kadar karbohidrat tertinggi yaitu pada perlakuan $\mathrm{R} 1$ dengan menggunakan ragi 05 gram terhadap 50 gram biji lamun dengan total karbohidrat $16.24 \%$, sedangkan kadar karbohidrat yang terendah yaitu padaperlakuan R3 dengan pemberian ragi 15 gram terhadap biji lamun sebanyak 50 gram jumlah kadar karbohidrat sebanyak $5.49 \%$. Jadi, Penurunan kadar ini disebabkan oleh penambahan kosentrasi ragi, semakin tinggi konsentrasi ragi yang ditambahkan maka semakin banyak pula khamir yang tumbuh dan berkembang biak.

\section{Kadar Lemak Berdasarkan Tingkat Pemakaian Ragi}

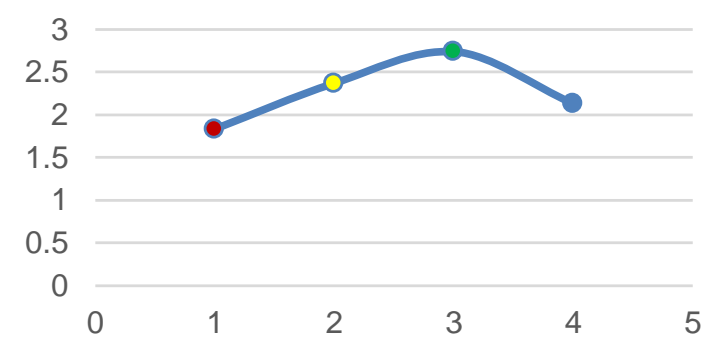

(Data primer, 2018)

Ket: R0 (Biji Lamun Mentah)

$\mathrm{R} 1$ (tempe dengan ragi 05 gram)

$\mathrm{R} 2$ (tempe dengan ragi 10 gram)

R3 (tempe dengan ragi 15 gram)

Kandungan lemak pada tempe berbahan dasar biji lamun yang dianalisis menggunakan metode soxhlet. Biji lamun mentah memiliki kadar lemak yang berbeda setelah diolah menjadi tempe biji lamun, dan memiliki hasil yang berbeda-beda disetiap pemberian konsentrasi ragi yang berbeda pula yaitu kadar lemak pada biji lamun mentah adalah $1.83 \%$ sedangkan pada R1 dengan menggunakan 05 gram ragi memperoleh $2.37 \%$ kadar lemak, selanjurnya R2 memiliki kadar lemak $2.74 \%$ dengan pemberian 10 gram ragi dan pada R3 dengan kadar ragi 15 gram menghasilkan kadar lemak sebanyak $2.13 \%$.

Perlakuan R2 tempe biji lamun menghasilkan kadar lemak tertinggi yaitu $2.74 \%$ sedangkan perlakuan terendah yaitu pada R3 dengan lemak $2.13 \%$. hal ini disebabkan karena adanya penambahan ragi, Rhizopus oligosporus yang dapat menghidrolisis lemak. Jamur menggunakan lemak dari tempe atau substrat sebagai sumber energinya (Iljas, dkk, dalam Deliani, 2008). Pendapat yang sama dikemukkan Nurminah (2013), bahwa semakin tinggi kosentrasi ragi maka kadar lemak semakin menurun disebabkan konsentrasi ragi yang tinggi mempengaruhi kapang dalam menguraikan lemak pada substrat selama fermentasi. Selain itu, adanya aktivitas enzim lipase yang dapat memecah lemak menjadi asam-asam lemak.

Penurunan kadar gizi pada penelitian ini sama dengan Astawan, (2004) yang menyatakan bahwa perubahan komposisi gizi selama proses pembuatan tempe 
disebabkan oleh perlakuan fisik maupun enzimatis akibat aktivitas mikroorganisme. Meskipun mengalami penurunan tetapi tempe biji lamun ini sangat baik bagi tubuh karena adanya enzim pencernaan yang dihasilkan oleh kapang menggakibatkan tempe biji lamun ini layak dikonsumsi oleh segala kelompok umur karena lebih mudah dicerna oleh tubuh.

\section{SIMPULAN}

Biji lamun mentah jika diolah menjadi tempe dapat meningkatkan kadar karbohidrat dan lemaknya jika kadar takaran raginya sesuai, pada penelitian ini peneliti menggunakan perbandingan 50 gram biji lamun dengan takaran 05 gram ragi menunjukan kadar karbohidrat tertinggi, sedangkan pada lemak kadar tertingginya dengan jumlah takaran ragi sebanyak 10 gram.

\section{DAFTAR PUSTAKA}

AOAC. 2005. Official Methods of Analysis. Association of Official Analytical Chemists. Benjamin Franklin station, Washington.

Astawan, M. 2004. Tetap Sehat Dengan Produk Makanan Olahan. Solo: Tiga Serangkai.

Deliani. 2008. Pengaruh Lama Fermentasi Terhadap Kadar Protein, Lemak, Komposisi Asam Lemak, dan Asam Fitat Pada Pembuatan Tempe. TESIS. Universitas Sumatera Utara. Medan .

Gifari, A. 2011. Karakteristik Asam Lemak Daging Keong Macan (Babylonia spirata), Kerang Tahu (Meretrix meretrix), dan Kerang Salju (Pholas dactylus). Skripsi. Institut Pertanian Bogor (tidak dipublikasikan)

Purba, L, L., Ginting, S., \& Nurminah, M. 2013. Perbandingan Berat Kacang Kedelai Bergerminasi dan Biji Nangka dan Konsentrasi Larut Pada Pembuatan Tempe. Jurnal Rekayasa Pangan dan Pertanian 2013; 1(2).

Kasmidjo, R.B., 1990. TEMPE: Mikrobiologi dan Kimia Pengolahan serta Pemanfaatannya. PAU Pangan dan Gizi UGM. Yogyakarta.
Koswara S. 1995. Teknologi Pengolahan Kedelai. Jakarta: Pustaka Sinar Harapan.

Koswara, S. 2006. Konsumsi Lemak Yang Ideal Bagi Kesehatan. Ebook pangan. http://ebookpangan.com. Diakses pada tanggal 14 Januari 2019.

Kuantraf J. Kuantaraf K. 1999. Olahraga Sumber Kesehatan. Percetakan Advent Indonesia: Bandung.

Lestari, O.A. \& Mayasari, E. Potensi Gizi Tempe Berbahan Dasar Jagung. Jurnal IImiah Teknosains. Jurnal IImiah Teknosains 2016; 2(2): 112-115.

Muskitta, M., 2016. Analisis Kadar Protein Pada Acoroides Milk Berdasarkan Suhu dan Lama Penyimpanan. Skripsi Program Studi Pendidikan Biologi, FKIP, Universitas Pattimura (tidak dipublikasikan).

Nuriana, W. Pemanfaatan Limbah Biji Nangka Sebagai Tepung dan Keripik. Jurnal Angritek 2009; 9(2).

Pawiroharsono, Suyanto. Potensi Pengembangan Industri dan Bioekonomi Berbasis Makanan Fermentasi Tradisional. Jurnal IImu Kefar. Indo. 2007: 5(2): 85-91.

Siregar N.S. Karbohidrat. Jurnal IImu Keolahragaan 2014; 13(2):38-44.

Ristia E, 2014. Perbandingan Kadar Gizi Tempe Biji Nangka dan Tempe Kedelai. Program Studi Pendidikan Biologi. Jurusan PMIPA, Universitas Tanjung Pura. Pontianak (Artikel Penelitian).

Rumiantin R.O. 2011. Kandungan Fenol, Komponen Fitokimia dan Aktivitas Antioksidan Lamun Enhalus acoroides. Departemen Teknologi Hasil Perairan. Fakultas Perikana dan IImu Kelautan. IPB Bogor. Skripsi.

Subagio, A., Hartanti, S., Windrati, W. S., Unus, ., Fauzi, M., \& Herry, B. Kajian Sifat Fisikokimia dan Organoleptik Hidrolisat Tempe Hasil Hidrolisis Protease. Jurnal Teknologi Dan Industri Pangan 2012; 13(3): 204.

Tuapattinaya P.M.J. Pengaruh Lama Penyimpanan Terhadap Kandungan Serat Kasar Tepung Biji Lamun (Enhalus acoroides) serta Implikasinya Bagi Pembelajaran Masyarakat Pulau Osi Kabupaten Seram Bagian Barat. Biosel: Jurnal Biologi Science and Education 2016; 5(1): 46-50. 